\title{
Meta Analisis Hasil Penelitian \\ Model-Model Rehabilitasi Narkoba oleh Lembaga Pemerintah, Masyarakat dan Pesantren di Jabodetabek
}

\begin{abstract}
Ismet Firdaus
Abstrak

The rehabilitation victims of drug abuse in Indonesia is not only done by government agencies, but also by NGOs and Pesantren. With this type of study, meta-analysis of 15 analytical research report, the results illustrated that in government agencies and non-governmental organizations, program therapeutif community (TC) becomes an important part in the Social Rehabilitation to clients of drug abusers, with the support of family and interaction among clients/patients harmony in social rehabilitation program is an important factor for the improvement or cure the patient/client victims of drug abuse. Detoxification (expenditure toxins drugs to patients/clients) that exist in government agencies and NGOs about the same, while in boarding school detoxification is different, for example by drinking water prayer. Meanwhile, the rehabilitation program in Islamic schools put more emphasis on improving the client's relationship with God through the practice of worship ritual which he believed to be implicated in healing drug abusers clients.
\end{abstract}

Key Words: Meta analisis, Rehabilitasi Medis, Rehabilitasi Sosial, TheraputifCommunity dan Narkoba.

\section{Pendahuluan}

Pada saat ini penyalahgunaan narkoba di Indonesia sangat mengkhawatirkan, Badan Narkotika Nasional (BNN) mencatat angka prevalensi dari Berdasarkan data terbaru tahun 2012, tercatat ada 3,7-4,7 juta penduduk Indonesia yang menjadi pecandu narkoba (narkotika dan obat/bahan berbahaya). permasalahan narkoba tiap tahun di Indonesia semakin meningkat, laporan BNN menyebutkan antara tahun 2005-2008 tercatat jumlah kasus sebagai berikut 2005 (16.252 kasus), 2006 (17.355 kasus), 2007 (22.630 kasus) dan 2009 (29.359 kasus) serta 2012 (32.743) (Profil leaflet Dit IV/Narkoba/BNN, 2012: 1). Sedangkan jumlah angka kematian pecandu pada kisaran 15.000 orang per tahun per tahun 41 orang meninggal per hari atau hampir 2 orang meninggal setiap jamnya. Korban lebih banyak meninggal (Sumber BNN). Yang terkena kasus penyalahguna tidak hanya orang biasa, tetapi juga kaum selebritas contohnya Fariz RM, Roy Marten, Sammy Vokalis Kerispatih, Rivaldo, Gary Iskak, Yoyo band padi dan yang paling banyak diberikan media massa adalah kasusnya Raffi Ahmad.

Dadang Hawari, hasil penelitiannya menyatakan bahwa penyalahgunaan NAPZA menimbulkan dampak antara lain: merusak hubungan kekeluargaan, menurunkan kemampuan belajar, ketidakmampuan untuk membedakan mana yang baik dan buruk, perubahan perilaku menjadi anti-sosial, merosotnya produktivitas kerja, gangguan kesehatan, mempertinggi kecelakaan lalu-lintas, kriminalitas, dan tindak kekerasan lainnya. (Dadang Hawari, 2004: 267-268). Banyaknya kasus tersebut mendorong pemerintah membuka layanan rehabilitasi di rumah sakit dan panti-panti rehabilitasi. Seperti RSKO, rehabilitasi teraputic community BNN di Cawang dan Lido Sukabumi, dan bahkan puskesmas-puskesmas di Jakarta, serta panti -panti dibawah kementerian sosial dan dinas sosial. Disamping itu, masyarakat juga dengan berbagai model pendekatan rehabilitasi dengan berbagai pendekatan keagamaan dan alternatif turut serta membuka layanan tersebut baik berbasis LSM maupun institusi keagamaan. Hal ini, menjadi kajian yang menarik bagi para akademisi untuk melakukan penelitian terhadap model-model rehabilitasi yang 
dilakukan oleh pemerintah dan swasta tersebut. Hasil riset yang ada diberbagai perpustakaan tersebut akan menjadi lebih menarik jika dianalisis dan dikomparasikan sehingga terlihat persamaan dan perbedaan serta keunggulannya. Oleh karena itu, bagi penulis menjadi cetusan untuk menelusuri hasil-hasil penelitian berkaitan dengan rehabilitasi Narkoba. Penusuran dilakukan dengan mengumpulkan dari berbagai media dan hasil penelitian. Kemudian hasil analisis para peneliti narkoba tersebut akan dipetakan dan dianalisis.

\section{Metode Penelitian}

Berdasarkan tujuan penelitian yakni untuk mendeskripsikan model-model hasil penelitian rehabilitasi narkoba berdasarkan pendekatan medis, agama, sosial/kemasyarakatan, alternatif atau campuran dari lembaga pemerintah, lembaga swadaya masyarakat kemudian dianalisis. Maka, penelitian ini mengambil jenis penelitian deskriptif. Menurut Neuman "Descriptive research present a picture of the specific details of situation, social setting, or relatif " (penelitian deskriptif menampilkan gambaran situasi, seting sosial, atau hubungan yang lebih rinci). Selanjutnya, penelitian ini menggunakan pendekatan kualitatif. Menurut Bogdan dan Taylor dalam Syamsir Salam pendekatan kualitatif, sebagai prosedur penelitian, menghasilkan data deskriptif berupa kata-kata tertulis atau lisan dari orang-orang dan perilaku yang diamati (Syamsir Salam, 2006: 30). Metode Pengumpulan data utama yang akan digunakan dalam penelitian ini adalah studi dokumen. Studi dokumen adalah suatu cara memperoleh data dengan melakukan penelusuran data melalui telaah terhadap karya ilmiah hasil penelitian berupa, laporan penelitian, jurnal, skripsi, dan tesis yang relevan dengan masalah yang sedang diteliti. sedangkan majalah, surat kabar, sumber internet menjadi dokumen pelengkap. Jumlah sampel dalam penelitian adalah 15 laporan penelitian berupa skripsi dan tesis dipilih secara purposif sampling. Dengan rincian sebagai berikut: 6 hasil penelitian rehabilitasi di panti pemerintah, 6 hasil penelitian rehabilitasi di LSM, dan 3 hasil penelitian rehabilitasi di pesantren.

\section{Landasan Teori: Meta Analisis Rehabilitasi Narkoba}

Meta analisis menurut Parson “... adalah analisis yang concern pada aktivitas analisa atau dapat disederhanakan dengan "analyzing analysis. Sedangkan menurut Stroup, meta analisis adalah sebuah pendekatan sistematis untuk mengidentifikasi, meninvestigasi, mensintesa dan (jika mungkin) menyatukan berbagai hasil penelitian yang relevan untuk menghasilkan kesimpulan yang menyeluruh. Salah satu keuntungan dari meta analisis adalah sebuah pendekatan sistematis untuk mengidentifikasi, menginvestigasi, mensintesa dan (jika mungkin) menyatukan berbagai hasil penelitian yang relevan untuk menghasilkan kesimpulan yang menyeluruh (Stroup, D.F. et. All, 2000). Meta analisis dalam penelitian kualitatif menurut Paterson dilakukan dengan mengsintesakan outcome (hasil penelitian) dari case study. Perbedaan yang mendasar antara sintesa kuantitatif dan kualitatif adalah kualitatif meta-analisis intinya melakukan interpretative dari pada aggregative. Sedangkan pada kuantitatif melakukan analisis pada statistical data analysis. Pada kualitatif meta-analysis seorang peneliti menganalisa tekstual reports, membuat interpretasi baru dalam proses (Peterson \& M. Dewis, 1998: 57).

Rehabilitasi atau reformasi (dua istilah ini dapat saling dipertukarkan) seringkali dikaitkan dengan rehabilitasi bagi pelaku kejahatan. Walaupun begitu, istilah ini juga dapat diterapkan pada siapa saja yang membutuhkan bantuan untuk problem pribadi dan social (Bagus Aryo, 2005: 8). Versi Modern dari rehabilitasi pada dasarnya sama; tujuannya untuk membuat si penderita menjadi lebih baik, yaitu memperbaiki posisi sosial atau pribadi pelaku kejahatan (the offender). Para pendukung rehabilitasi berpendapat bahwa pelanggaran (the offence) hanya gejala dari suatu permasalahn yang terjadi dengan sendirinya sebagai akibat cacat kepribadian 
sosial. Jika Permasalahannya disembuhkan, maka gejala atau dorongannya untuk melakukan kejahatan pun akan hilang pula (Ibid:9). Dalam UU No. 35 Tahun 2009 tentang Narkotika membagi Rehabilitasi menjadi dua yaitu rehabilitasi medis dan rehabilitasi sosial. Rehabilitasi Medis adalah suatu proses kegiatan pengobatan secara terpadu untuk membebaskan pecandu dari ketergantungan narkotika. Rehabilitasi Medis pecandu narkotika dapat dilakukan di Rumah Sakit yang ditunjuk oleh Menteri Kesehatan. Yaitu rumah sakit yang diselenggarakan baik oleh pemerintah, maupun oleh masyarakat. Selain pengobatan atau perawatan melalui rehabilitasi medis, proses penyembuhan pecandu narkotika dapat diselenggarakan oleh masyarakat melalui pendekatan keagamaan dan tradisional. Rehabilitasi Sosial adalah suatu proses kegiatan pemulihan secara terpadu baik secara fisik, mental maupun sosial agar bekas pecandu narkotika dapat kembali melaksanakan fungsi sosial dalam kehidupan masyarakat. Yang dimaksud dengan bekas pecandu narkotika disini adalah orang yang telah sembuh dari ketergantungan terhadap narkotika secara fisik dan psikis (BNN, 2009: 3). Definisi lainnya dari kementerian sosial, Rehabilitasi sosial yaitu suatu rangkaian kegiatan profesional yang bertujuan memecahkan masalah, menumbuhkan, memulihkan dan meningkatkan kondisi fisik, psikis, mental dan sosial agar dapat menjalankan fungsi sosialnya. (Depsos, 2003: 3). Model-model pelayanan Rehabilitasi Sosial adalah 1) Model pelayanan dan rehabilitasi medis, 2) Model pelayanan dan rehabilitasi sosial dengan pendekatan bimbingan sosial dan kelompok. 3). Model pelayanan dan rehabilitasi sosial dengan pendekatan keagamaan. 5). Model pelayanan dan rehabilitasi sosial dengan pendekatan terpadu. (ibid: 5)

Narkoba (Narkotika, obat Psikotropika dan bahan berbahaya). Kata narkotika berasal dari bahasa Inggris yaitu " narcotics " yang berarti obat yang menidurkan atau obat bius. (S. Warjowarsito, 1980: 122). Menurut UU Narkotika Nomor 35 tahun 2009 Narkotika adalah zat atau obat yang berasal dari tanaman atau bukan tanaman, baik sintetis maupun semisintetis,yang dapat menyebabkan penurunan atau perubahan kesadaran, hilangnya rasa, mengurangi sampai menghilangkan rasa nyeri, dan dapat menimbulkan ketergantungan, yang dibedakan ke dalam golongan- golongan sebagaimana terlampir dalam UndangUndang ini. Psikotropika sebagaimana narkotika juga dijelaskan pada UU No 5 tahun 1997 adalah: Zat atau obat, baik yang alamiah maupun yang sintesa bukan narkotika, yang berkhasiat psikoaktif melalui pengaruh selektif pada susunan syaraf pusat yang menyebabkan perubahan khas pada aktivitas mental dan perilaku. Bahan Berbahaya Adalah zat, bahan kimia dan biologi, baik dalam bentuk tunggal maupun campuran yang dapat membahayakan kesehatan dan lingkungan hidup secara langsung atau tidak langsung yang mempunyai sifat, karsinogenik, teratogenik, mutagenik, korosif dan iritasi. Bahan berbahaya ini adalah zat adiktif yang bukan Narkotika dan Psikotropika atau Zat-zat baru hasil olahan manusia yang menyebabkan kecanduan. Bahan berbahaya yang dapat menimbulkan adiktif berupa ketagihan, kecanduan atau ketergantungan. Dalam turunan jenisnya yang dijelaskan oleh Dadang Hawari, zat adiktif ini terdiri dari yaitu: Sedativa dan hipnotika, Amatamin dan Halusinogen, Fensiklisida serta Inhilasia, Solven, Nikotin, dan Kafein.

\section{Pemerintah (Panti Putra Galih Pakuan Kementerian Sosial RI di Bogor, Rumah Sakit Ketergantungan Obat (RSKO), Unit Terapi dan Rehabilitasi Badan Narkotika Nasional LIDO-BOGOR)}

Cucu Maesaroh meneliti tentang pelaksanaan konseling di Panti Putra Galih Pakuan Bogor yang berapa dibawah naungan Kemensos RI. Tahapan rehabilitasi di Galih Pakuan, Bogor meliputi ; 1) Persiapan, 2). Penerimaan klien, 3) Assesment, 4) Pembinaan fisik dan bimbingan sosial, 5) Resosialisasi, 6) Pembinaan lebih lanjut. Hasil penelitian menjelasakan bahwa pelaksanaan konseling dalam proses rehabilitasi dip anti sosial ini pada dasarnya membantu klien mengatasi permasalahan perubahan perilaku dan emosional sebagai efek negatif dari penyalahgunaan narkoba, melalui penggalian sumber-sumber dan 
meningkatkan kemampuan-kemampuan yang dimiliki klien secara lebih efektif. Dampak konseling, dari informasi yang diberikan klien (informan), bahwa proses konseling yang diberikan konselor telah mengubah beberapa perilaku negatif (Cucu Maesaroh, 2002: 90-100). Meskipun demikian, Lutuedo (2000: 65) dalam penelitiannya juga di Galih Pakuan bahwa pada umumnya klien penyalahguna tidak panti tersebut tidak tersosialisasikan dengan baik berkaitan dengan pengetahuan yang cukup mendasar dari lembaga tersebut, seperti apa tujuannya, sasaran pelayanannya, dan mengapa dilakukan beragam jenis bimbingan yang ada di panti tentunya terkait dengan bagaimana mereka dapat memanfaatkan program tersebut. Melihat hal demikian ini, maka tidak mengherankan bila para penyalahguna mempersepsikan bahwa proses rehabilitasi di panti kurang maksimal. Reaksi penyalahguna terhadap pelaksanaan rehabilitasi yang tidak sesuai dengan apa yang diharapkan ini diyakini akan menimbulkan permasalahan dalam kasus rehabilitasi sehingga tujuan yang ingin dicapai dari kegiatan rehabilitasi tidak akan tercapai. Hasil analisis Nina, (Rini Riyanti Januarita, 2013: 5357) menyatakan bahwa pada tahun 2013 pelaksanaan rehabilitasi dengan pendekatan TC di panti PSPP Galih Pakuan ini sudah terjadwal secara rapih dan teratur. Tahapan yang harus dilalui klien/residen adalah tahap orientasi dan konsultasi, mengidentifikasi,memotivasi, seleksi dan penerimaan. Pada tahap ini dilakukan pengungkapan dan pemahaman masalah, waktu pelaksanaan tahap ini 30 hari. Dengan hasil assesment yang diperoleh, maka pekerja sosial yang bertanggung jawab pada klien/residen ini dibuat rencana perubahan yang diharapkan yang akan didiskusikan dalam sidang kasus (case conference) yang dihadiri oleh kolega seprofesi dan profesi lainnya seperti psikolog dan dokter. Berdasarkan kesimpulan hasil case conference, pekerja sosial yang menangani klien/residen ini menyusun rencana intervensi atau program rehabilitasi sosial yang sesuai dengan kebutuhan dan kondisi klien. Setelah diadakan intervensi lalu diadakannya penyusunan intervensi, maka dilakukan pelaksanaan intervensi dengan pendekatan TC. Lamanya program TC ini yaitu 12-24 bulan tergantung dari kondisi residen itu sendiri. Setelah mengikuti program TC kemudian residen melaksanakan magang kerja selama 30 hari sesuai dengan bimbingan keterampilan yang diperoleh dari panti ini. Hasil penelitian ini juga menyimpulkan bahwa Program TC ini telah membantu meningkatkan interaksi sosial klien/residen. Karena program TC ini menyediakan banyak forum bagi residen untuk melakukan kontak dan komunikasi inter personal yang bersifat teraputik (penyembuhan).

Temuan Penelitian Amelia (2009: 70-71), bahwa pertama, jenis dan fasilitas pelayanan RSKO adalah melayani pasien dengan ketergantungan obat dengan atau yang memiliki komplikasi (HIV/AIDS) dan pasien umum (bukan ketergantungan obat) yang mengikuti terapi rumatan: metadon dan buprenorfin, program rumatan metadon adalah salah satu program yang ada di RSKO, metadon itu sendiri adalah sintetik dari heroin, setiap orang yang telah menggunakan heroin lebih dari satu tahun dan telah pernah mencoba program detoksifikasi dan minimal usia 18 tahun baru boleh mengikuti program rumatan metadon ini. Dalam program rumatan metadon didepan petugas dan mengikuti pertemuan kelompok dukungan sebaya setiap minggu. Setiap dua bulan sekali diadakan pertemuan kelompok dukungan sebaya setiap minggu. Setiap dua bulan sekali didakan pertemuan keluarga pasien. Untuk rumatan buprenorfin, pasien datang tiap kurun waktu yang telah ditetapkan oleh dokter yang menanganinya. Petugas pada layanan rumatan metadon dan farmasi mempunyai tugas supervisi dan distribusi metadon ke satelit-satelit (8 puskesmas dan 2 lapas) serta mengadakan pertemuan tiap tiga bulan dengan seluruh satelit di RSKO) dan memberi pelayanan dan konseling NAPZA dan HIV/AID. Poliklinik NAPZA: melayani pasien ketergantungan NAPZA, yang meliputi ketergantungan opiate, ganja (mariyuana), heroin,kokain, pil Koplo (lexaton), atau obat psikostimulan (ectacy, shabu-shabu) dan lain-lain. Pelayanan poli NAPZA terdiri dari: Non Rumatan: 
Senin-Jum'at, jam 09.00 - 13.00 WIB, dan Rumatan: Setiap hari, jam 09.00 - 15.00 WIB. Instalasi Gawat Darurat. IGD merupakan pelananan 24 jam, yang tujuan utamanya mengatasi kondisi "life Saving" misalnya kasus overdosis NAPZA. Observasi dilakukan 1 x 6 Jam. Instalasi Rawat Inap. Instalasi rawat inap memberikan fasilitas program dianataranya: Program Detoksifikasi: 1) Memiliki kapasitas 10 tempat tidur; 2) Mengatasi gejala putus obat. 3). Detoksifikasi heroin, alcohol dan benzodiazepine. 4). Dilakukan evaluasi secara menyeluruh: fisik, mental dan sosial.; 5). Tindak lanjut dengan pengobatan jangka panjang. Program Rehabilitasi Fasilitas yang dimilikinya, antara lain: 1). 30 tempat tidur, merupakan suatu perawatan jangka panjang dengan pendekata medis; Psikologis, sosial dan spiritual; 3). Melibatkan berbagai macam profesi seperti: dokter, perawat, psikiater, psikolog, pekerja sosial,konselor adiksi, pembimbing rohani dan dokter spesialis lainnya; 4). Pendekatan program merupakan gabungan antara model medis, theraputic community (TC) 12 langkah, pendidikan, kesehatan, rekreasional, dan intervensi psikososial, baik yang bersifat indidual, kelompok maupun keluarga; 5) Perencanaan terapi bersifat individual. Kedua, hasil penelitian ini juga menjelaskan tentang konseling pasien Narkoba, yang dilaksanakan setelah pasien menjalani evaluasi sosial, yakni identitas diri klien sudah lengkap dan juga berkaitan dengan data keluarga klien. Selanjutnya pasien/ klien dapat berkonsultasi dengan dokter, konselor, psikolog, pekerja sosial secara sendiri atau bersama keluarga. Metode yang digunakan dalam pelayanan konseling di RSKO adalah pertama, metode directive, dimana metode ini bertujuan untukmembantu pasien supaya dapat mengubah perilakunya terutama yang berkaiatan dengan emosional dan impulsif dengan perilaku yang rasional, disadari (sengaja), secara akurat dan waspada. Kedua,komunikasi dua arah, dimana konselor harus dapat menguasai bagaimana dapat mengali dan memahami masalah pasien dengan cara penerapan keterampilan konseling seperti mendengar aktif, kontak mata, bahasa yang mudah dimengerti, being silent, dan edukasi yang tepat. (Ibid: 72-77). Sedangkan Israwati (1995) dalam penelitiannya di RSKO, mengungkapkan bahwa dalam rehabilitasi penyalahguna narkoba, salah satu teknik yang dapat digunakan adalah konseling kelompok. Konseling kelompok ini sebagai sarana yang dapat digunakan untuk mengatasi masalah-masalah individu melalui penyediaan lingkungan kelompok yang mendukung penyembuhan. Salah satu latihan yangditerapkan dalam konseling kelompok ini adalah latihan ketegasan, dimana para anggota dapat belajar mempraktikan tingkah laku baru (sikap tegas) dalam suasana aman. Disamping itu, peranan dan bimbingan orang tua mutlat diperlukan untuk mendukung penerapan tingkah laku baru tersebut. Dalam hal inikesabaran dan kebesaran hati orang tua sangat diperlukan. Dan yang paling penting adalah kemauan keras dari peserta konseling kelompok untuk bersikap tegas dalam membentengi diri dari pengaruh buruk serta keinginan kuat untuk melepaskan diri dari jerat narkoba. Dalam proses konseling kelompok ini peserta mempelajari dan melatih diri untuk bersikap asertif. Peran konselor dalam konseling kelompok ini adalah sebagai guru yakni memberikan pendidikan pada anggota-angota konseli (kelompok terapi) tentang bagaimana cara-cara bersikap asertif.

Seperti diungkapkan diatas, orang tua atau keluarga klien berperan penting dalam proses keberhasilan rehabilitasi. Partisipasi mereka terhadap lembaga (RSKO) secara langsung maupun tidak langsung akan mempengaruhi keberhasilan program lembaga. Yudha dalam penelitiannya di RSKO pada tahun 2000 mengungkapkan bahwa dari 20 keluarga sampel dari klien RSKO, hanya $5 \%$ dari mereka yang memiliki pengetahuan yang baik tentang program pengobatan dan perawatan. Sementara, sisanya mengaku belum menanyakan pada petugas. Disamping itu, sikap perhatian dan harapan keluarga pun cenderung negatif. Dalam pertanyaan-pertanyaan yang terpisah, terlihat $65 \%$ keluarga penyalahguna setuju perilaku merokok klien,karena dianggap tidak ada pengaruhnya pada proses penyembuhan; $45 \%$ keluarga 
penyalahguna akan memberikan apa saja asal klien senang; $45 \%$ klien menentukan sendiri terhadap program terapi yang diinginkannya; $45 \%$ keluarga penyalahguna akan menjenguk bila klien minta dijenguk; $65 \%$ penyalahguna mempercayai setiap informasi yang datang dari klien. Maria Ulfah. (2011) menganalisis bahwa penerapan metode theraputic community yang ada di teori ini hampir keseluruhannya sesuai dengan metode theraputic community di tempat rehabilitasi Unitra dan dijalankan dengan baik dan tersusun dari morning meeting, morning briefing, open hause, encounter group, semina, general meeting, community group (vocational/workshop, probe, extended, marathon), dengan jadual masing-masing kegiatan yang ditemukan oleh peneliti pada tempat rehabilitasi unitra. Walaupun ada perbedaan yang ditemukan oleh peneliti pada baian penempatan hak-hak (previledge) para residen, tetapi sebagian besar pada intinya sama. Dan penekanan peraturan hanya pada residen sedangkan untuk mayor rules dan house rules tidak peneliti temukan direhabilitasi residen female. Keunggulan dan kelemahan dalam metode theraputic community dapat diihat dari pendapat konselor dan residen bahwa keunggulan lebihmendominasi karena perubahanperubahan yang residen rasakan langsung selama mengikuti program theraputic community. Dari segi kelemahan mereka tidak menganggapnya sebagai kendala yang besar, karena kendala itu hanya ada pada diri mereka dan mereka dapat mengatasinya dengan baik. Respon dari para residen ini memberikan tanggapan yang baik setelah mereka dapat melewati program theraputic community.

Lembaga Swadaya Masyarakat (Yayasan Titihan Respati (YTR), Yayasan Madani Mental Health Care, Yayasan Al- Jahu).

Program rehabilitasi dengan pendekatan Theraputic Community (TC) di Yayasan Titihan Respati (YTR) merupakan suatu bentuk perawatan korban penyalaguna narkoba secara terpadu. Tujuan dari program TC meliputi: a. memberikan suatu penanganan yang bersifat menyeluruh melliputi penanganan terhadap aspek-aspek perkembangan dalam diri residen (sebutan bagi klien TC di YTR) yang meliputi perilaku, emosi, psikologis, intelektual, spiritual dan vocasional; dan b) menciptakan suatu lingkungan penyembuhan yang kondusif bagi proses penanganan residen. Proses rehabilitasi yang diselenggarakan oleh di YTR, terdiri dari beberapa tahapan yang meliputi: a. Entry; b) orientasi; c. primery d. Reentry dan Aftercare. Metode yang digunakan dalam program rehabilitasi di YTR meliputi wawancara langsung, menggunakan panduan formulir seleksi, dan menggunakan buku panduan "Walking paper" dan "Sistem Buddy, aktivitas, pemberian penekanan timbale balik, model peran konseling individu dan konseling keluarga. Staf pelaksana program rehabilitasi di YTR terdiri dari para staf profesional dan staf para professional seperti para alumni residen. Pada Program TC ini dalam prosesnya diarahkan untuk membangkitkan kembali semangat hidup, rasa percaya diri, tanggung jawab, motivasi untuk berkarya, belajar serta berpikir, bersikap dan bertindakj secara positif. Peranan konselor dan seluruh staf dalam pelaksanaan program pendidikan dengan nmenunbuhkan dan membina suasana program yang membantu penghuni untuk tetap menjalani program pemulihan direhabilitasi sampai selesai. Cara-cara yang dilakukan para staf dan konselor dalam mengelola kegiatan program adalah dengan menggunakan teknik kekeluargaaan, serta pendekatan konseling keluarga atau berupa seminar bagi orang tua yang bertujuan agar orang tua dapat berperan dalam proses penyembuhan anaknya. (Ferlinda Cristianingrum, 2002: 78-85). Selanjutnya, Rusli (2001) juga menjelaskan tentang metode Therapeutif Community di Yayasan Titihan Respati. Dari studi literatur diketahui bahwa dalam modelintervensi yang dilakukan sifatnya bertahap. Sebelum menjalankan program Re-entry, seseorang residen harus mengikuti tahap sebelumnya yaitu primary. Pada tahap primary, seorang residen diberikan behavior management dengan pengawasan yang ketat dengan 
tujuan untuk merubah perilaku residen yang semula negatif menjadi positif. Tetapi program ini saja tidak cukup untuk mempersiapkan residen kembali kemasyarakat. Karena itu diperlukan program Re-entry. Pada program ini, nilai yang diajarkan lebih aktual dan disesuaikan dengan dinamika masyarakat. Karena tidak semua nilai yang diajarkan pada tahap primary bisa diterapkan sepenuhnya. Pada tahap ini residen kembali dihubungkan denga lima aspek penting kehidupan yaitu ketuhanan, kemasyarakatan, pentingnya sekolah dan bekerja, mengatur keuangan pribadi dan kekeluargaan. Residen diharuskan mempunyai aktivitas diluar yang dilakukan secara bertahap untuk melatih menghadapi ancaman-ancaman yang terjadi diluar. Penelitian lainnya di YTR yang dilakukan Noorina P. Mahdayani (2000), ia menganalisis tentang penyesuaian diri orang tua terhadap anaknya sebelum dan sesudah menjadi residen YTR) dengan membuat dua kategori provoking dan enabling. Hasilnya, ada informan orang tua yang menerapkan perilaku provoking dalam usaha untuk mengubah perilaku anaknya yang ditandai dengan dominasi respon yang ditampilkan adalah: a. eksprresi kemarahan secara verbal berkepanjangan berupa argument-argumen sengit atau kritikan yang dilakukan secara berulang-ulang dan terkadang disertai ancaman kepada anak, b. perilaku mengontrol dan mengawasi gerak-gerik anak yang dilakukan secara terus menerus. Adapun perilaku enabling yang mendominasi respon orang tua ini tampil dalam bentuk: a.Membantu anaknya sehingga anaknya tidak terlihat sedang bermasalah dengan narkoba, b. menyerah pada keinginan anak dan memberikan dukungan keuangan dan memberikan fasilitas kemudahan anak, c. usaha-usaha yang memanipulasi atau mengontrol (dengan cara menciptakan) suatu situasi tertentu untuk anak yang dianggap dapat menyenangkan diri anak sehingga diharapkan dapat melupakan narkoba. Dampak menyesuaian diri yang provoking dari hasil penelitian menunjukan bagi anak yaitu: adanya perasaaan serba salah dalam apapun yang diperbuat, $b$ tekanan emosional yang berakibat, gelisah (uring-uringan), energy menurun, tidak bisa tidur, mendapatkan masalah dalam pergaulan sosial. Setelah anak masuk ke dalam program Yayasan Titihan Respati yang ternyata juga merupakan terapi tidak hanya bagi anak korban penyalahguna juga bagi orang tua. dimana orang tua dalam program YTR diminta turut aktif. Hasilnya perilaku provoking orang tua mengalami perubahan, dimana respon orang tua dapat dimasukan dalam kategori derachment, yaitu: a. Mengajak anak berdiskusi untuk mencari jalan keluar masalah, b. Tidak terjebak lagi dalam perilaku yang terus-menerus mengontrol gerak-gerik anak, melainkan dengan tetap memberikan kebebasan dan juga kepercayaan kepada anak, namun juga memberikan batasanbatasan yang harus dipenuhi. c. Tidak lagi menjadikan masalah gangguan ketergantungan narkoba sebagai tema utama dalam komunikasi dengan anak. d. orang tua mulai dapat menguasai emosi. e. Orang tua tidak merasa malu atas masalah yang menimpa anaknya; f. Orang tua dapat lebih percaya kepada anak, karena anak menemukan positif peer, yaitu kawan-kawannya ditempat rehabilitasi, h. Orang tua dapat lebih menfokuskan diri dalam menemukan solusi yang tepat dalam mengatasi masalah yang sedang dihadapi anak dengan melakukan pendekatan pada anak dan juga dengan meminta saran dari orang tua sesama penderita, I orang tua menemukan dunia baru yang menyenangkan, yaitu duania sesama orang tua penderita dikarenakan masalah sama yang mereka hadapi. Begitu juga yang terjadi pada anak setelah mengikuti program rehabilitasi di Yayasan Titihan Respati, dimana ada interaksi antar orang tua dan keluarga dengan penderita ketergantungan Narkoba, dalam penelitian ini. Ketiga subyek wawancara juga mengubah persepsi mereka terhadap sikap orang tuanya, sebagai berikut: a. tidak lagi menganggap orang tua terlalu protektif atau pun strength, tetapi melihat hal-hal tersebut sebagai rasa kasih sayang orang tua terhadap anak seperti pada umumnya, b. dapat menjadi lebih terbuka akan setiap masalah kepada orang tua,c. merasa lebih senang dan dekat dengan orang tua dan keluarga mereka. (Ibid, 80-87) 
Jovendra Aliansyah (2013) menjelaskan bahwa Proses rehabilitasi di Yayasan Madani Mental Health Care adalah sebagai berikut; pertama terapi medik yaitu stabilisasi pencucian racun tanpa anestesi dan subtitusi. Artinya tidak menggunakan bahan-bahan kimia atau zat adiktif. Kedua, dengan menggunakan terapi religius yang meliputi berdzikir, mengaji, shalat, mengkaji al-qur'an dan hadist, serta mengajarkan klien tentang syukur nikmat dari Allah SWT. Ketiga, terapi psikososial ini ditujukan untuk mengembalikan klien untuk menguatkan cita-cita dan tekad yang kuat, mengajarkan interaksi sosial dan sosialisasi kepada masyarakat dan keluarga. Disamping itu juga diajarkan pengetahuan tentang kesadaran diri dan mengadakan latihan-latihan sharing person atau pendekatan secara emosional terhadap orang lain. Keempat, melatih keterampilan klien sesuai dengan kemampuan yang dimiliki klien. Keterampilan ini memadukan pengetahuan secara umum yang dapat berbentuk latihan bahasa Inggris dan Arab, Komputer, seni lukis, desain, teknik cetak sablon, Tata boga, handicam, Service Handphone, dan lain-lain, sesuai dengan kemampuan masing-masing.

Lina Sari (2001) dalam hasil penelitian tentang sistem pelaksanaan rehabilitasi di Yayasan Al-Jahu. Pertama, menjelaskan tentang variabel input. Temuanya bahwa pada aspek tenaga kerja dari kuantitas dan kualitas menurutnya sudah cukup memadai. Selanjutnya, dari aspek sarana, dan dana pun dinilai cukup dan bersumber dari pasien dan donatur pribadi. Sedangkan untuk pelatihan staf, terutama konselor untuk terapi 12 langkah yayasan ini belum menyelenggarakan, karena staf konselornya belum banyak, maka lebih efisien menurut pimpinan yayasan dengan mengikutsertakan konselor di lembaga lain. Proses rehabilitasi ada klien yang dilakukan oleh yayasan ini adalah detoksifikasi, terapi 12 langkah, kegiatan rohani, terapi kerja dan didukung oleh kegiatan olah raga dn refresing. Selain itu, yayasan Al-Jahu hanya menerima pasien/klien laki-laki saja. Dalam menerapkan program treatment terapi 12 langkah dilaksanakan setiap hari. Dalam terapi ini kelekatan antar pasien penyalahguna dan penyalahguna dengan konselor adalah kunci suksesnya. Ada beberapa kasus pasien yang sifatnya sangat tertutup dan merasa bosan, maka proses rehabilitasi akan berjalan tidak baik. Oleh karena itu, keterampilan dan keahlian seorang konselor untuk membangun kepercayaan pasien sangat penting, karena tanpa ada kerjasama berupa keterbukaan pasien proses rehabilitasi akan menjalani hambatan. Faktor lain yang menentukan keberhasilan rehabilitasi adalah kedisiplinan konselor dalam mematuhi jadwal yang sudah dibuat. Monitoring perkembangan hasil rehabilitasi dilakukan oleh konselor dan salah satu pasien yang ditunjuk pengurus Al-Jahu untukmengawasi teman-temannya. Dari hasil penelitian terungkap bahwa kegiatan paling menarik dan disenangi oleh pasing adalah forum sharing kelompok. Pengaruh program terapi 12 langkah terhadap pasien dapat mereaka rasakan selama menjalani program rehabilitasi. Secara kognitif, dari hasil penelitian, para pasien hafal dan memahami terapi 12 langkah.

\section{Pesantren Hikmah Syahadah, dan Modern Ichsan, Bogor}

Siti Izzatul Yazidah (2001) memaparkan tentang tentang pelaksanaan terapi ilahiyah di Pondok Pesantren Hikmah Syahadah di Kp. Kedondong Desa Pasir Nangka Rt.002/03 Kecamatan Tiga Raksa Kabupaten Tangerang. Tes Wawancara da Detoksifikasi. Pada awalnya pengurus melakukan beberapa tahapan bagi santri baru, seperti tes wawancara mengenai latar belakang keluarga dan riwayat penyakit atau bodi chek. Setelah melakukan beberapa tahapan baru lah para santri ditempatkan di kamar yang disesuaikan dengan emosional santri dan melakukan upaya detoksifikasi. Detoksifikasi adalah upaya pemutusan pasien dengan NAPZA, artinya pada saat itu pasien sudah tidak diperbolehkan lagi mengkonsumsi NAPZA. Terapi ini bersifat sebagai pertolongan pertama bagi pasien untuk bisa pulih kembali akibat pengaruh obat seperti muntah-muntah, hidung meler, tidak bisa tidur dan lain sebagainya. Masa detoksifikasi di Ponpes Hikmah 
Syahadah ini berlangsung 10 hari sampai 1 bulan lamanya,hal itu tergantung pada tingkat perubahan klien, selama menjalani detoksifikasi,pasien hanya menjalani terapi ilahiyah dengan dibantu ramuan herbal, seperti air kelapa yang mampu menetralisir obat-obatan, pada tahap ini pihak pompes juga sama sekali tidak menggunakan obat-obatan medis, sekalipun pasien mengalami sakau. Adapun detoksifikasi dengan cara medis, pada fase ini pembersihan darah dan sirkulasi organ-organ tubuh lainnya pada tubuh pecandu dari narkotika, psikotropika atau zat adiktif lainnya, sehingga darah menjadi bersih dan sistem metobolisme tubuh kembali nornal. Proses ini dapat dilakukan melalui cara-cara sebagai berikut: 1) Cold Turkey (absurt witdrawal) yaitu proses penghentian pemakaian Narkoba secara tiba-tiba tanpa disertai dengan substansi antidotum. 2) Bertahap atau substitusi bertahap, misalnya dengan Kodein, Methadon, CPZ, atau Clocaril yang dilakukan secara tap off (bertahap) selama 1-2 minggu. 3) Rapid Detoxification: Dilakukan dengan anestesi umum (6-12 jam). 4) Simtomatik: tergantung gejala yang dirasakan. Hal ini sangat berbeda dengan upaya pengeluaran racun Narkoba dalam tubuh pasien di Ponpes rehabilitasi Hikmah Syahadah yang sama sekali tidak menggunakan obat-obatan medis apalagi memberikan Narkoba dengan dosis yang sangat rendah (misalnya metadon), jadi begitu pasien masuk mendaftarkan dirinya sebagai pasiifikasen tersebut tengah mengalami sakau. Maka, di sinilah kelebihan dari pengobatan pasien Narkoba di Pondok pesantren Hikmah Syahadah karena pasien tidak merasakan efek kimia dari obat-obatan medis. Setelah menjalani detoksifikasi atau tahap penanganan awal, maka pasien mengikuti serangkaian pelaksanaan terapi ilahiah. Berikut ini langkah-langkahnya. Minum Air Do'a Air do'a ini merupakan air khusus yang telah dibacakan ayat-ayat syifa, ayat-ayat syifa tersebut yaitu surat al-Falaq, an-Nas, al-Ikhlas, al Fatihah, al-Baqarah ayat 1-7, ayat kursi dan at-Taubah. Minum air do'a ini juga merupakan anjuran Rasulluhlah karena mampu menyerap energi positif ke dalam tubuh. Minum air do'a dilakukan sebelum melaksanakan terapi telunjuk petir dengan tujuan agar air positif tersebut menjalar ke seluruh tubuh, menyerap ke seluruh syaraf-syaraf dan memperlancar peredaran darah, atau ibarat kata sambil disuntik dibantu dengan minum obat. Terapi Gurat Telunjuk Petir. Terapi telunjuk petir adalah terapi yang dilakukan dengan cara mengguratkan jari ke titik-titik syarat tubuh pasien yang dibarengi dengan do'a dan dibasuhkan air do'a, sehingga adanya energi positif yang masuk kedalam tubuh si. Ada pun teknik pelaksanaan terapi telunjuk petir yaitu sebagai berikut: Duduk menghadap kiblat Membaca syahadah Meminum air do'a: Membubuhkan air do'a ke ubun-ubun pasien Mulai menguratkan jari ke daerah kepala seperti kening, bawah telinga dan tengkuk kepala. Gurat pada bagian dada dan Gurat pada bagian punggung Gurat pada bagian tangan Gurat pada bagian kaki seperti paha depan/belakang dan betis. Terapi ini dilakukan empat kali dalam seminggu, yakni pada malam minggu, malam senin, malam rabu dan malam jum'at. Jumlah guratan tersebut harus ganjil yakni antara 7-11 kali guratan, apabila isi pasien merasakan kesakitan yang luar biasa, maka diwajibkan untuk membaca kalimat tasbih, tahmid dan takbir. Hal tersebut juga diperjelas oleh Rasyid Fadhly "Memang kalau awal-awal menjalani terapi ini pasien sangat kesakitan bahkan ada yang sampai muntah-muntah maka sesakit apapun, si pasien harus mengucap asma Allah. " Rendy pun mengalami rasa sakitnya terapi ini,berikut cerita Rendy (salah satu pasien): “Waktu pertama mah memang sakit banget, tapi setelah itu badan jadi terasa enteng, jadi nafsu makan dan tidur nyenyak, eh sekarang mah saya jadi ketagihan pengen diterapi terus, jadi udah gak terlalu sakit kayak pas awal-awal aja. "Selanjutnya Terapi Mandi Malam. Terapi ini bertujuan untuk menghilangkan pengaruh obat karena air tersebut sudah dicampur dengan garam dan dibacakan do'a, terapi mandi malam ini dilaksanakan pada malam hari yaitu pada malam jum'at pada pukul 24:00 WIB, atau menunggu air tersebut benar-benar dingin sehingga pasien merasa menggigil. Dari tujuh kulah yang ada, telah dipercaya khasiatnyadari masing- 
masing kulah tersebut. Biasanya kulah yang dipakai untuk mandi malam adalah kulah yangk eempat, teknik pelaksanaannya yaitu dengan cara berendam dan satu kuah digunakan untuk 1-3 orang.

Mengenai Layanan konseling bagi penyalahguna di Pondok Pesantren Modern Ichsan, Bogor, Zuriah (2001) mengungkapkan bahwa peredaran narkoba yang semakin sulit dibendung sekarang ini turut memperbanyak jumlah para pasien penyalahguna narkoba dipanti rehabilitasi yang tersebar dibeberapa wilayah di Jakarta. Kesimpulan dari penelitian ini adalah: a) Program layanan konseling kelompok (berupa dhuha meeting) bagi para pasien penyalahgunaan narkoba yang telah dijalankan pada pusat rehabilitasi pesantren modern Darul Ichsan secara umum sudah cukup baik dan memadai. Pembina yang tersedia di pusat rehabilitasi masih sangat terbatas terutama pada latar belakang pendidikan Bimbingan dan Konseling atau psikologi secara umum. Kebanyakan mereka adalah lulusan perguruan tinggi Islam, khususnya dari IAIN jurusan tarbiyah dan dakwah. Mungkin lembaga ini meninikberatkan pada pemantapan jiwa keislaman pada para santri dalam rehabilitasinya sehingga dibutuhkan para pengasuh atau Pembina yang mengerti dan mendalami masalah-masalah keagamaan. b. Tempat rehabilitasi sudah sangat baik dan nyaman bagi para pasien. Hal ini dimaksudkan agar para pasien merasa cukup betah dan tidak cepat merasa bosan dalam menjalani proses penyembuhan yang berlangsung cukup lama.. c. Materi yang telah ditetapkan dalam proses layanan konseling kelompok sudah cukup memadai dan sedikit ada sinkronisasi dengan usulan penulis. Ternyata memang cukup sulit untuk mengelola kelompok pasien penyalahgunaan narkoba karena mereka tergolong orang yang mempunyai "defence mechanism" yang sangat tinggi. Proses penyembuhan mereka mutlat memerlukan dukungan dari keluarga sebagai basis pertanhanan pertama dan utama.

\section{Meta Analisis}

Berdasarkan analisis data, rehabilitasi atau proses penyembuhan bagi korban penyalahgunaan narkoba dapat dilakukan dengan beberapa model rehabilitasi. Di Panti Pemerintah yang berada dibawah naungan kementerian Sosial, Rehabilitasi medis dari temuan tidak menjadi titik perhatian yang penting. Sedangkan di RSKO, Rehabilitasi Medis menjadi tahap yang penting.

Bila menganalisis dari hasil analisis, bahwa panti rehabilitasi narkoba pemerintah yang berada di bawah naungan Kementerian Sosial menempatkan rehabilitasi sosial, berada pada tahap keempat dari tahapan rehabilitasi. Dari hasil analisis Cucu Maesaroh bahwa Rehabilitasi Sosial di RSPP Galih Pakuan berupa konseling, yakni model rehabilitasi sosial yang menekankan pada bimbingan individu dan kelompok. Dari hasil analisis bahwa proses konseling yang diberikan konselor telah mengubah beberapa perilaku negatif mereka. Ada analisis menarik dari Lutuedo bahwa pada umumnya klien penyalahguna tidak panti tersebut tidak tersosialisasikan dengan baik berkaitan dengan pengetahuan yang cukup mendasar dari lembaga tersebut. Model rehabilitasi sosial yang diterapkan adalah dengan Theraputic community yang Lamanya program TC ini yaitu 12-24 bulan tergantung dari kondisi residen itu sendiri. Setelah mengikuti program TC kemudian residen melaksanakan magang kerja selama 30 hari sesuai dengan bimbingan keterampilan yang diperoleh dari panti ini. Hasil analisis penelitian ini menyatakan bahwa Program TC ini telah membantu meningkatkan interaksi sosial klien/residen. RSPP Galih Pakuan Hasil analisis Cucu Maesaroh ini sejalan dengan hasil analisis Maria Ulfah hal ini terjadi karena program TC ini menyediakan banyak forum (morning meeting, moorning briefing, confrontion, seminar, static group, olah raga, kegiatan keagamaan, bimbingan keterampilan, sharing,circle, SNA (Saturday night activity)) P.A.G.E. (peer, personal accountability group evaluation). bagi residen untuk melakukan kontak dan komunikasi inter personal yang 
bersifat teraputik (penyembuhan). Forum ini mengakibatkan kemampuan komunikasi interpersonal residen meningkat mereka bisa berbicara dengan baik dengan sesama residen, para petugas panti. Mereka dalam berinteraksi sosial misalnya dalam mengeluarkan dan mendengarkan pendapat menjadi lebih baik, mampu menyesesaikan masalahnya dengan kelompok atau komunitasnya melalui interaksi sosial yang inten dengan pendekatan TC ini. Tetapi, hasil analisisnya menyatakan bahwa kurangnya dukungan pimpinan panti, kepala panti jarang berinteraksi dengan residen, menjadi hambatan lainnya dalam proses rehabilitasi sosial dengan pendekatan ini, Disamping itu ada beberapa kasus residen mengalami penurunan daya tangkap dalam komunikasi akibat komsumsi NAPZA, sehingga interaksi sosial kurang berjalan dengan baik, selanjutnya, adanya beberapa orang tua atau keluarga residen kurang mendukung program TC ini sehingga proses penyembuhan kurang berjalan dengan baik. Hasil analisis Amelia, bahwa metode konseling pasien NAPZA di RSKO, yang digunakan dalam pelayanan konseling adalah metode directive, yakni metode ini bertujuan untuk membantu pasien supaya dapat mengubah perilakunya terutama yang berkaitan dengan emosional dan impulsif dengan perilaku yang rasional, disadari (sengaja), secara akurat dan waspada. Kedua, komunikasi dua arah, dimana konselor harus dapat menguasai bagaimana dapat mengali dan memahami masalah pasien dengan cara penerapan keterampilan konseling seperti mendengar aktif, kontak mata, bahasa yang mudah dimengerti, being silent, dan edukasi yang tepat. Menganalisis hasil analisis Israwati dalam penelitiannya di RSKO,mengungkapkan bahwa rehabilitasi penyalahguna narkoba, salah satu teknik yang dapat digunakan adalah konseling kelompok. Konseling kelompok ini sebagai sarana yang dapat digunakan untuk mengatasi masalah-masalah individu melalui penyediaan lingkungan kelompok yang mendukung penyembuhan. Salah satu latihan yangditerapkan dalam konseling kelompok ini adalah latihan ketegasan, dimana para anggota dapat belajar mempraktikan tingkah laku baru (sikap tegas) dalam suasana aman. Disamping itu, peranan dan bimbingan orang tua mutlat diperlukan untuk mendukung penerapan tingkah laku baru tersebut. Dalam hal ini kesabaran dan kebesaran hati orang tua sangat diperlukan. Dan yang paling penting adalah kemauan keras dari peserta konseling kelompok untuk bersikap tegas dalam membentengi diri dari pengaruh buruk serta keinginan kuat untuk melepaskan diri dari jerat norkoba. Dalam proses konseling kelompok ini peserta mempelajari dan melatih diri untuk bersikap asertif. Peran konselor dalam konseling kelompok ini adalah sebagai guru yakni memberikan pendidikan pada anggota-angota konseli (kelompok terapi) tentang bagaimana cara-cara bersikap asertif. Seperti diungkapkan diatas, orang tua atau keluarga klien berperan penting dalam proses keberhasilan rehabilitasi. Partisipasi mereka terhadap lembaga (RSKO) secara langsung maupun tidak langsung akan mempengaruhi keberhasilan program lembaga.

Sedangkan pada Lembaga Swadaya Masyarakat dapat di analisis bahwa yayasan Titihan Respati (YTR) dalam rehabilitasi sosial juga sama dengan panti pemerintah dengan menngunakan TC. Dari hasil menganalisis dari analisis Cristianingrum yang berbeda dengan panti pemerintah adalah adanya cara-cara yang dilakukan para staf dan konselor dalam mengelola kegiatan program adalah dengan menggunakan teknik kekeluargaaan, serta pendekatan konseling keluarga atau berupa seminar bagi orang tua yang bertujuan agar orang tua dapat berperan dalam proses penyembuhan anaknya. Pentingnya dukungan orang tua dan keluarga mengacu pada hasil analisis Mahdayani pada orang tua dan pasien RSKO yang menyatakan bahwa perilaku provoking orang tua mengakibatkan adanya perasaaan serba salah pada anaknya dalam apapun yang diperbuat, tekanan emosional yang berakibat, gelisah (uring-uringan), energy menurun, tidak bisa tidur, mendapatkan masalah dalam pergaulan sosial. Adapun perilaku enabling orang tua menghasilkan: anak tidak lagi menganggap orang tua terlalu protektif atau pun strength, tetapi melihat hal-hal tersebut 
sebagai rasa kasih sayang orang tua terhadap anak seperti pada umumnya, dapat menjadi lebih terbuka akan setiap masalah kepada orang tua, dan merasa lebih senang dan dekat dengan orang tua dan keluarga mereka. Berbeda dengan RSKO, Temuan Jovendra Aliansyah bahwa proses rehabilitasi di Yayasan Madani Mental Health Care adalah terapi medik yaitu stabilisasi pencucian racun tanpa anestesi dan subtitusi, artinya tidak menggunakan bahan-bahan kimia atau zat adiktif. Kedua, dengan menggunakan terapi religius yang meliputi berdzikir, mengaji, shalat, mengkaji al-Qur'an dan hadist, serta mengajarkan klien tentang syukur nikmat dari Allah SWT. Ketiga, terapi psikososial ini ditujukan untuk mengembalikan klien untuk menguatkan cita-cita dan tekad yang kuat, mengajarkan interaksi sosial dan sosialisasi kepada masyarakat dan keluarga. Disamping itu juga diajarkan pengetahuan tentang kesadaran diri dan mengadakan latihan-latihan sharing person atau pendekatan secara emosional terhadap orang lain. Keempat, melatih keterampilan klien sesuai dengan kemampuan yang dimiliki klien. Sedangkan pada Yayasan Al- Jahu, dari analisis Lina Sari tentang sistem pelaksanaan rehabilitasi di Yayasan Al-Jahu proses rehabilitasi pada klien adalah detoksifikasi, terapi 12 langkah, kegiatan rohani, terapi kerja dan didukung oleh kegiatan olah raga dn refresing. Selain itu, yayasan Al-Jahu hanya menerima pasien/klien laki-laki saja. Dalam menerapkan program treatment terapi 12 langkah dilaksanakan setiap hari. Dalam terapi ini kelekatan antar pasien penyalahguna dan penyalahguna dengan konselor adalah kunci suksesnya. Dari hasil penelitian terungkap bahwa kegiatan paling menarik dan disenangi oleh pasien adalah forum sharing kelompok. Pengaruh program terapi 12 langkah terhadap pasien dapat mereaka rasakan selama menjalani program rehabilitasi. Secara kognitif, dari hasil penelitian, para pasien hafal dan memahami terapi 12 langkah.

Sedangkan pada rehabilitasi berbasis pesantren, dari analisis Wiwin Wirdaningsih, bahwa Terapi Tarekat Qadiriyah Naqsabandiyah dalam penyembuhan Korban Narkotika di Pondok Inabah melalui 4 tahap yaitu tahap penerimaan (initial intake), tahap detoksifikasi, tahap assesment, dan tahap pembinaan dan bimbingan (terapi). Tahap detoksifikasi dengan cara cold turkey, yakni membiarkan anak bina dalam keadaan putus obat. Kemudian baru pada tahap pra-rehabilitasi, anak bina dipersiapkan untuk memasuki bimbingan (pembinaan) yang meliputi antara lain: pengenalan program, penciptaan kestabilan mental dan emosional serta membangkitkan motivasi untuk mengikuti program rehabilitasi. Selanjutnya, tahap assesment yang bertujuan untuk mengobservasi atau mereview kembali data pribadi yang berkenaan dengan latar belakang calon santri mengkonsumsi narkotika, jenis dan dosis serta tingkat keadiksiannya, penggalian bakat, minat dan potensi calon santri. Kemudian dilakukan kesepakatan atau kontrak pelayanan bimbingan, yang mencakup: pernyataan kesediaan calon santri dan orang tua dalam jangka waktu yang diperlukan, dan kesangupan mematuhi segalaperaturan yang berlaku di inabah. Setelah itu baru dilanjutkan dengan pelaksanaan bimbingan yang meliputi: tetapi mandi (hydro therapy), shalat, dan dzikir. Seangkan Shaum dan Ziarah mearah merupakan terapi penunjang. Siti Izzatul Yazidah memaparkan tentang tentang pelaksanaan terapi ilahiyah di Pondok Pesantren Hikmah Syahadah di Kp. Kedondong Desa Pasir Nangka Rt.002/03 Kecamatan Tiga Raksa Kabupaten Tangerang. Kalau dianalisis pada 2 tahap awal yaitu identifikasi dandetoksikasi memiliki kemiripan dengan pesantren Suryalaya yakni tidak menggunakan obat kimia. Namun ada penjelasan tentang masa detoksifikasi di Ponpes Hikmah Syahadah ini berlangsung 10 hari sampai 1 bulan lamanya dengan meminum air doa. Temuan penting dari hasil penelitian ini, bahwa rehabilitasi yang digunakan dengan "Terapi Gurat Telunjuk Petir". Sedangkan di Pondok Pesantren Modern Ichsan Bogor, berdasarkan analisis Zuriah yang menilai layanan konseling, rehabilitasi sosial di pesantren ini, sebagai berikut: pertama, Program layanan konseling kelompok (berupa dhuha meeting) bagi para 
pasien penyalahgunaan narkoba yang telah dijalankan pada pusat rehabilitasi pesantren modern Darul Ichsan secara umum sudah cukup baik dan memadai. Kedua, pembina yang tersedia di pusat rehabilitasi masih sangat terbatas terutama pada latar belakang pendidikan Bimbingan dan Konseling atau psikologi secara umum. Kebanyakan mereka adalah lulusan perguruan tinggi Islam, khususnya dari IAIN jurusan tarbiyah dan dakwah. Mungkin lembaga ini meninikberatkan pada pemantapan jiwa keislaman pada para santri dalam rehabilitasinya sehingga dibutuhkan para pengasuh atau Pembina yang mengerti dan mendalami masalah-masalah keagamaanTempat rehabilitasi sudah sangat baik dan nyaman bagi para pasien.

\section{Penutup}

Berdasarkan meta analisis data, maka dapat disimpulkan bahwa rehabilitasi atau proses penyembuhan bagi korban penyalahgunaan narkoba dapat dilakukan dengan beberapa model rehabilitasi. Di lembaga Pemerintah yang berada dibawah naungan kementerian Sosial, rehabilitasi medis dari temuan tidak menjadi titik perhatian yang penting. Sedangkan di RSKO, rehabilitasi medis menjadi tahap yang penting. TC menjadi bagian penting dalam rehabilitasi sosial di panti lembaga pemerintah dan lembaga swadaya masyarakat. di RSPP Galih Pakuan berupa konseling, yakni model rehabilitasi sosial yang menekankan pada bimbingan individu dan kelompok. Dukungan keluarga dan interaksi sesama klien/pasien yang harmonis dalam program rehabilitasi menjadi faktor penting untuk perbaikan pasien/klien korban penyalahgunaan narkoba. Detoksifikasi yang ada di lembaga Pemerintah dan LSM hampir sama, sedangkan detoksifikasi di Pesantren berbeda, misalnya dengan meminum air doa. Rehabilitasi di Pesantren lebih menekankan pada perbaikan hubungan klien dengan Tuhannya dengan pengamalan ibadah-ibadah ritual yang nantinya berimplikasi pada kesembuhan, Sedangkan pada lembaga pemerintah dan LSM dengan pendekatan TC yang menekankan pada perbaikan hubungan dengan sesama manusia pasca rehabilitasi medis.

Rekomendasi penelitian ini adalah pertama, perlunya penelitian primer komparasi dan evaluasi rehabilitasi penyalahgunaan Narkoba, sehingga dapat diketahui secara jelas keunggulan dan hasil dari metode rehabilitasi dari berbagai tempat rehabilitasi yang ada di Indonesia. Hal ini berguna untuk pengembangan akademis dan pembuat kebijakan dalampenangulangan bahaya narkoba. Kedua, dalam penelitian ini peneliti menemui kesulitan dalam menemukan judul penelitian yang sama di tempat rehabilitasi yang berbeda, sehingga untuk membandingkan menemui kesulitan, maka hal ini perlu dipertimbangkan bagi peneliti yang akan meneliti dengan pendekatan meta analisis. 


\section{Bibliografi}

\section{Buku}

Aryo Bagus, dkk. 2005. Permasalahan Narkoba di Jabodetabek, Jawa Barat, Jawa Timur dan Bali,

Lab.Kesos FISIP UI.

BNN, 2009.Undang-Undang No. 35 Tahun 2009 tentang Narkotika, Jakarta: BNN

D.F. Stroupet al. 2000. Meta Analysis of Observational Studies in Epidemiologi: A proposal for Reporting. JAMA, April 19, vol 283, no. 15

Direktorat Jendral Pelayanan dan Rehabilitasi Sosial Depsos RI, 2003. Standarisasi Pelayanan dan Rehabilitasi Sosial Korban NAPZA dalam Panti, Jakarta: Depsos.

Dirdjosisworo Soedjono. 1990. Hukum Narkotika Indonesia, Bandung: Citra Aditya Bakti

Gerungan DIPL, 1996. Psikologi Sosial, Bandung: Eresco, , Cet ke-11

Hawari Dadang, Psikiater, 2004..Al-Qur'an Ilmu Kedokteran Jiwa dan Kesehatan Jiwa, Yogya: PT.

Dana Bhakti Prima Yasa,, Edisi III, Cet ke-X

Hawari, Dadang, 1996. Konsep Islam Memerangi AIDS dan NAZA, Yogyakarta: Dana Bhakti Prima Yasha.

Hurlock Elizabeth B., 1990. Psikologi Perkembangan, Suatu Pendekatan Sepanjang Rentang Kehidupan, Jakarta: Penerbit Erlangga, Cet ke-5

Hawari Dadang, 1996. Al-Quran Ilmu Kedokteran Jiwa dan Ilmu Kesehatan Jiwa, Jakarta: PT Dhana Bhakti Prima Yasa.

ILO, 2004. Anak-anak Dalam Perdagangan dan Produksi Obat-obatan Terlarang di Jakarta, Jakarta: Organisasi Perburuhan Internasional, , Cet. Ke-1

Joewana Satya. 1989. Gangguan Penggunaan Zat, Jakarta: PT Gramedia.

Kamus besar Bahasa Indonesia. 1998, Jakarta, Balai Pustaka, Depdikbud

Mubarok Achmad, 2000. Solusi Krisis Keruhanian Manusia Modern, Jiwa da Al-Quran. Jakarta: Paramadina.

Profil Leaflet Dit IV/Narkoba/BNN, 2012

Syamsir Salam, 2006. Metode Penelitian Sosial , Jakarta: UIN Jakarta Press.

Syahrudin Darwis, 1999. Musyaruddin, Mari Bersatu Berantas Bahaya Penyalahgunaan NARKOBA (NAZA) BP, Dharma Bhakti: Jakarta.

Thorne, Peterson, B.L. S., \& Dewis M.. 1998. Adapting to Managing Diabetes. Image. Journal of Nursing Scholarship 30 (1), hlm. 57-62.Warjowarsito S. Tito, 1980. Kamus Lengkap Bahasa Inggris-Indonesia, Indonesia-Inggris. Bandung.

\section{Hasil Penelitian}

Amelia. 2009. Pelayanan Konseling pada Rehabilitasi Pasien NAPZA di Rumah Sakit Ketergantungan Obat ( RSKO) Cibubur Jakarta Timur. Skripsi UIN Jakarta Jurusan Bimbingan dan Penyuluhan Islam

Aliansyah Jovendra, 2013. Rehabilitasi Mental Remaja Korban Penyalahgunaan Narkoba di Yayasan Madani Mental Health Care Cipinan Besar Selatan Jakarta Timur, Skripsi BPI UIN Jakarta 
Cristianingrum Ferlinda, 2002. Penerapan Pendekatan Theraputic Community Pada Program Rehabilitasi Remaja Korban Penyalahguna NAPZA Studi Deskriptif pada Yayasan Titihan Respati Periode 2000-2001, Prodi Kesejahteraan Sosial FISIP UI.

Ivvone, Lutuedo, 2000. Persepsi Remaja Eks Ketergantungan Obat Terhadap Proses Rehabilitasi di Panti Sosial Pamardi Putra “Galih Pakuan” Kabupaten Bogor Jawa Barat. Tugas Karya Akhir, Sekolah Tinggi Kesejahteraan Sosial, Bandung.

Israwati, 1995. Penerapan Konseling Kelompok Pendekatan Asertif pada Respon para Remaja Penyalahguna Zat Adiktif untuk mengatasi Tekanan Teman Kelompok sebuah Studi Deskriptif pada RSKO Cilandak, Jakarta (skripsi) Depok: Ilmu Kesejahteraan Sosial FISIP UI.

Januarita, Nina Riyanti, 2013. Interaksi Sosial Para Pengguna NAPZA dalam mengikuti Metode Theraputic Community di Panti Sosial Pamardi Putra (PSPP) “ Galih Pakuan” PUTAT NUTUG-BOGOR, Skripsi Jurusan Bimbingan dan Penyuluhan Islam FIDKOM.

Maesaroh Cucu, 2002. Pelaksanaan Konselingpada Proses Rehabilitasi Sosial Klien Penyalahgunaan Napza, Studi Deskriptif pada panti Sosial Pamardi Putra "Galih Pakuan, Putat Nutug, Kabupaten Bogor. Magister Sains (M.Si) Tesis, Kekususan Kesejahteraan Sosial, Program Studi Sosiologi, FISIP UI, Depok.

Mahdayani Noorina Prametty, 2000. Penyesuaian Diri Orang Tua Terhadap Anak Yang menderita

Ketergantungan NAPZA dan Persepsi Anak tentang penyesuaian diri tersebut Studi Kasus di Yayasan Titihan Respati, Skripsi: FKM UI, Depok.

Rusli Rusmarni, 2001. Pendidikan Alternatif Bagi Remaja Yang Mengalami Ketergantungan Narkoba, Studi Kasus di Rehabilitasi Yayasn Titihan Respati Jakarta, Skripsi: UNJ.

Sari Lina, 2001. Analisis Sistem Pelaksanaan Program Rehabilitasi Terhadap Penyalahgunaan

NAPZA (Narkotika, Psikotropika, Zat Adiktif lainnya) Di Yayasan Al JAHU, Jakarta Selatan, Skripsi ; FKM UI

Saifuddin, 1998. Penanggulangan Eks Korban Obat Atau Eks KKO Yang Telah Mendapatkan Pelayanan di Pesantren Suryalaya di Kabupaten Dati II Tasikmalaya. Tugas Karya Akhir Sekolah Tinggi Kesejahteraan Sosial, Bandung

Ulfah Maria, 2011. Metode Theraputic Community bagi Residen Narkotika Di Uit Terapi dan Rehabilitasi Badan Narkotika Nasional LIDO-BOGOR, Skripsi BPI UIN Jakarta

Wirdaningsih Wiwin, 2004.Peranan Terapi Tarekat Qadiriyah Naqsabandiyah Dalam Penyembuhkan Korban Narkotika Di Pondok Inabah VII Pesantren Suryalaya, Tasikmalaya. Skripsi: BPI UIN Jakarta

Yazidah Siti Izzatul, 2011. Pelaksanaan terapi ilahiyah di Pondok Pesantren Hikmah Syahadah di Kp. Kedondong Desa Pasir Nangka Rt.002/03 Kecamatan Tiga Raksa Kabupaten Tangerang. Skripsi: Kesejahteraan Sosial FIDKOM

Zuhriah, 2001. Studi Deskriptif Layanan Konseling Kelompok bagi Pasien Penyalahgunaan NAZA (Narkotika, Alkohol, Zat Adiktif lainnya) di Pusat Rehabilitasi Pondok Pesantren Modern Darul Ichsan, Cariu Bogor, Skripsi: UNJ 